\title{
Abraham - the father of dialogue in three major world faiths
}

\section{Emil JURCAN*}

Abstract: Abraham is for the three religions (Judaism, Christianity and Islam) the chance of dialogue and the recovery of a relationship that ends religious disputes and extremism. His presence as Father of so many peoples and faiths can be the starting point for the recovery of the revelational monotheism. Unfortunately, however, it seems that for the Islamic-Jewish world Abraham remains another cause of tension. It is the tomb of Abraham in Horeb. Our study tries to present the importance of Abraham beyond any political-religious tension.

Keywords: Abraham, Christianity, Islam, Judaism, monotheism.

We permanently feel that the lack of a genuine dialogue among followers of Islam, Christianity and Judaism is caused by the fact that we have not found yet the common point of discussion or the gateway to a positive relationship. Of course there are certain ideas that need to be overcome in this beginning of dialogue. Each of the three faiths should review their way of approaching spiritual alterity. A different perception of dialogue is therefore needed, one that goes beyond the restrictive way of these positioning.

* Rev., PhD, Professor, Faculty of Orthodox Theology at "1 Decembrie 1918" University, Alba Iulia, Romania. Contact: emiljurcan@yahoo.com. 
Let us take Judaism for example. It should come out of the sphere of the Hebrew ethnocentrism. In Jesus' time, the Jews were very zealous in making proselytes. The same thing happened when Islam began, when there were many Bedouin tribes who had embraced Jewish monotheism. The other Arabian tribes were also governed by this idea of abrahamic monotheism ${ }^{1}$ and they were later banished or massacred. The fact that at Pentecost (Acts of the Apostles, Chapter 2) the Apostle Peter spoke to the three thousand proselytes and Jews proves that then there was another mentality regarding the Jewish ethno-religion. Certainly, due to the isolation or self-separation from medieval societies more or less open to communion, the Jews created a religious enclave mentality, which led to an ethnicization of Judaism. It is probably the elite theory adopted by some Jewish leaders, who consider that not everyone can become a member of the Jewish religion and Jewish ethnoreligious community.

There is also a lot of hostility in the relation to Christians or Muslims. But the Jews remember the Holocaust, although we believe that whoever kills in the name of any ideology, even if baptized, is no longer a Christian. In other words, what happened at Auschwitz and in other camps was not the work of a mind and of a Christian faith, but of people who had no trace of holiness and divinity left in them. And if the Vatican and the Nazi Germany signed a a concordat, the former should bear the blame for its actions and ask for forgiveness for this reckless way of thinking. This anti-Christian mentality, coming from the idea of the Holocaust, should be dismissed from mind, because it was not the Christians who killed people, but the faithless people. And Christians should not accuse the Jews of the formation of communism, because it was not the Jews who had created it, but

${ }^{1}$ See Christopher CATHERwood, A Brief History of the Meddle East. From Abraham tu Arafat, Carroll and Graff Publisher, New York, 2006. 
some atheist leaders introduced this horrible system, that produced more victims than those in the concentration camps.

In Islam's relationship with Judaism, the latter had to create his own modus vivendi. And sometimes Judaism was accused of collaborationism, if we think of Andalusian Spain. For the Jews, all their history was a way of living together and subsistence in different parts of the world and under the political-administrative structures down the ages. Perhaps their way of thinking, which turned them into an intelligent and resourceful people, changed them into a rather wealthy group envied by the cohabiting populations. The fact that this people had been prepared and cultivated since childhood was their strength. In a world where almost $95 \%$ of the population was illiterate, apart from clergy and some noblemen, and no one was educated, when the Jews were about 7 to 10 years old, they were taken to the synagogue to be given the Bar Mitzvah ceremony, that is to read and comment on the Torah, which meant they could write and read. That is why the Jews were to be found at the courts of the European kings as doctors, scholars or tax collectors. They are said to have been very demanding and unyielding people in order to collect taxes for their masters. This conduct helped the Jews to excel in finance and start all great European banks. But on the other hand, this ascension to (economic, political or cultural) power made the vain peoples of the old continent envious. In the German space, where the ethnic Stolz was so strong, it was very difficult for another ambitious and powerful population to live there, too.

In the Islamic world, the situation was not different; on the contrary. Although people were mislead to believe that the Christians and the Jews were doing well, things have not been so. Indeed, there were crusades in the Holy Land, but let us sum up a few things: 
1. It was not the crusaders who invaded the territory of Islam, but the other way round. The Holy Land was populated by the Christians and the Jews. Most of the Jews had been deported since the time of the Roman emperor Hadrianus after Bar Kochba's last uprising (135 AD). So it was not the Christians to blame for the Jews' exodus. There may have been fanatic Christians, but that was not Jesus' teaching. We state that again: whoever kills in the name of Christ is not a Christian. Christian is the one who protects himself/herself in the name of Christ because he/she protects his/her faith, family and country, not just him/herself.

2. The Muslims invaded the land of Israel as well as other areas (Syria, Mesopotamia, Persia, India, North Africa etc.), and the Christians tried to protect these populations and their faith. Islam was spread by the sword, not by preaching the Quran. On the contrary, the Christian mission was not accomplished by the use of sword (such cases were exceptions and unsuccessful), but by preaching the Gospel. Jesus said: "In the same way, let your light shine before others, that they may see your good deeds and glorify your Father in heaven." (Matthew 5:16).

3 . There were eight crusades, but these were only attempts to recover Christian holy places from Muslim control. So the first to draw the sword were the Islamists, not the crusaders.

4. The Crusaders wanted to make the holy places safe for the Christian pilgrims who visited them. The media and a certain part of the historiography, due to the evil desire to wipe out any trace of Christian principles from the consciousness of European man, altered history and presented the crusaders as hordes who invaded the peaceful Muslims. The latter, led by Saladin, managed to stand against the European barbarians of Europe at Kurûn Hattîn and they wrested control of the Holy Land.

5. Let us make a brief analysis of the battles. Ten crusades were organized by the Christians. The Muslims attacked the 
Christian world from Asia Minor to North Africa and Spain and the Balkans more than 450 times. So, there were more than 450 battles against which Christians tried to defend themselves, because it was not the Christians who invaded the Arabs, but Islam had descended upon Europe. It is well known how many battles our poor Romanian peasants fought against the welltrained janissary for military battles. About 270 million Christians died during this time. It is a significant number and we should think about it.

6. The Conditions of Omar that have been observed throughout the centuries in Islamic world, forbid Christians to ring church bells, to make renovations to old churches or build new ones. This is also true for today's Egypt, where hundreds of Christians die each year and no one takes up their cause.

7. For the first time in history, it was not the fascists who divided people by clothing system, but the Islam. That is, the star of David was encountereded on Jewish clothes in Islam, and Christians were not allowed to wear a turban, instead they wore a blue girdle as a distinctive sign. They also had to bow to any Muslim passing by. The question is what about the equal rights in Europe towards immigrants? It appears that we are nice and wellmannered people.

8. Finally, Mahommed's last wish before he died was that the entire Arabian Peninsula embraced Islam. And so it was at the expense of the Ridda Wars when hundreds of thousands of innocent people were killed, and their children and wives were traded as slaves. What are we talking about then? Which is the religion of love and which God is closer to all humanity? Today cowardice and fear make some people deny Christianity and hold it responsible for all the crimes in the world indiscriminately.

To conclude with, there was also fanaticism in Christianity, but that cannot be compared to the violence coming from Arabia that converted by the sword millions of people in India and Spain. 
Although the highly praised golden age of the abbesses is greatly spoken of, people tend to forget that while Aristotle's works were being translated into Arabic, the great libraries of India were burnt down and thousands of books or scrolls containing a vast amount of knowledge were destroyed.

And this was done for a simple reason, the so-called Quran's syllogism (the Quran contains all the knowledge of the world; those books which agree with the Quran are to be disposed of because the Quran is sufficient and they are superfluous. And if they have things which contradict the Quran, in which case they are heresy, so they also must be deposed of). Christians suffered greatly due to Muslim invasions.

No one suggests vengeance, because in such case we should lose our Christian energy and become subject to the law of retaliation. The authentic Christian spirituality believes in love and peace. First of all, the common point among all the three faiths is to be found. The theognosy of love should be looked after. God is the One who loves the whole world, He does not love parts of it or certain faiths. He awaits the return of any man to deep faith, and He loves every sinner, for he/she is His creation. So the idea of God-love is the first stage of the rapprochement among faiths and people. A God who supports wars is no longer legitimate, he is an idol that justifies our violence and disposition towards killing. Killing in the name of God means not having met the true God, but having created a chimera to justify our actions.

Secondly, it is about the anthropological concept. In terms of revelation, all men are created equal. We are all equal in Gods eyes. There are people who have already found God and people who are on their way to Him. Nothing entitles me, if I am a Christian and I believe that the revelation of divine love is authentic in Christ, to disregard the one who has not reached this kind of understanding. The moment I have felt superior to the 
other, my faith has failed and I have lost the agapic revelation. I can only be a true Christian when I love all man, imitating Christ's love. Jesus told the Jews that the faith he had found in the Roman centurion or in the Canaanite woman was greater than the one of the Pharisees. He stated that he did not choose among beliefs and people. He who believes that the Muslim is superior to the Christian or the Jew, or that the Christian is superior to the other two, is possessed by the spirit of pride. Obviously, we want all to reach the unity of faith, but the divine plan and help should be called upon, not the human pride.

The problem of religious violence should be viewed the same way by all three faiths. One cannot be faithful by hiding or concealing violent deeds or by accepting it from the pulpit. The role of the preacher is to spreak words of peace and comfort, not rousing the spirits and encouranging anger. It is not only the European world that is struggling with the violence of the Islamic terrorist groups, but also the whole authentic Islam, that wishes for a world full of peace and joy. The world is not divided into the House of Submission and the House of War and the whole planet is the house of God or its creation. In other words, there are expressions and doctrines that should be dismissed from mind, because they generated so much hatred and violence in the world by using them. If they continue to be accepted and promoted, then the future will be bleak. Terms such as jihad or holy war should be reduced to their original meaning if there was such a meaning, if not, they ought to be avoided when speaking, because neither normal people nor profound believers need them any more. The third millennium needs peace, and peace among people should be the only purpose. Faith can lead man's conscience towards non-violence. In history there were expressions that created tensions and these tensions degenerated into battles and bloodshed. It is those expressions that now should be eliminated from language. 
The presence of Abraham is the common point among all the three faiths. Who was Abraham ${ }^{2}$ ? Certainly everyone knows: the man of God coming from Mesopotamia to create a new consciousness among peoples, namely the monotheistic consciousness. Monotheism was present to all peoples, even to those who are polytheistic or dualistic today. We strongly believe that each faith is monotheistic when being analysed, because there is only one God. After the loss of revelation, man seeks the sacred and God. Having no real divine revelation, man's seeking is marked by religious or pseudo-religious variations. Myths are the expression of this quest. In illo tempore, these faiths had the anamnesis of a single God, and later myths divided Him in polytheistic variants of religions.

Abraham was from Ur of the Chaldees in Mesopotamia, a monotheistic city-state ${ }^{3}$. But later on, the Chaldean monotheism, which preserved the authentic revelation, combined with the Akkadian and Sumerian religions that offered a monotheism associated with polytheistic myths. In other words, the primary monotheism was corrupted by polytheistic myths and eventually the Zoroastrian dualism occurred in this area. Zoroastrianism was originally a monotheistic religion and in the end it became monotheistic again, because Ormizd or Ormazd defeated Ahriman and Good would triumph over evil in the world.

Abraham was born in Ur, one of the oldest cities and human settlements in history, which during the VI-III millennium

${ }^{2}$ „Abraham, or Abram of Ur, to give his original name, is someone believed in despite any direct historical evidence for his existence outside the scriptures of these three faiths. However, archaeological finds certainly confirm events contemporary to Abraham, and tie in with the accounts in the Hebrew Scriptures" Christopher CATHERwoOd, A Brief History of the Midlle East. From Abraham tu Arafat, p. 31.

3 Christopher CATHERwood, A brief History of the Midlle East. From Abraham to Arafat, Caroll and Graff Publisher, New York, 2006, p. 29. 
B.C. dominated Mesopotamian culture and religion, along with other cities in the area, such as Uruk or Kish. Ur is identified with Tell el-Muqayyar some $350 \mathrm{~km}$ southeast of Baghdad in Iraq, on the bed of the Euphrates River. Ur retained the monotheist belief that some of the people in the Old Testament were called upon to continue ${ }^{4}$. What appeared to be a very old city (dating back to the $6^{\text {th }}$ millennium B.C.) became a very important trade power since all the vessels that went to Baghdad passed by Ur.) However, the city of Ur slowly became one of the polytheistic cultures of that time, raising a huge ziggurat in honour of the Moon god, Nammu, whose shrine was in this immense structure.

According to the Hagadic and then the Koranic tradition, Terah, Abraham's father, was a great idol worshiper in Mesopotamia, while Abraham was not. According to the Hagadic analysis, the idolatry dispute is based on the idea that Abraham would have smashed all the idols'statues, except for one, the largest of all. When searching for the perpetrator, Abraham was asked if he had destroyed the statues, because he was known to be against idols. According to the narrative, Abraham suggested to ask the all knowing idol. That moment people realized those statues had no knowledge, being unable to communicate. Abraham would leave Ur, to go into the land of Canaan at the Oak of Mamre for that was the place God

had chosen for him. After his father died, Abraham did indeed depart from the city of Harran, in Southern Turkey, in the province of Sanliurfa (once called Edessa). Then he was headed for the land of Canaan, settling down South of Salem later called Jerusalem.

The encounter between Abraham and Melchizedek is a special one. The enigmatic figure of Melchizedek, king of Salem

${ }^{4}$ Bruce FeILER, Abraham. A Journey to the Heart of Three Faiths, Harper Collins Publisher, 2002, p. 38. 
and priest of God the Most High brought Abraham bread and wine after his return from the defeat of Chedorlaomer's forces who had conquered Sodom and Gomorrah. Although the information is not sure, Melchizedek's shrine and tomb is supposed to be on Mount Tabor. Melchizedek embodies the Old Testament's mystery of expecting a real, divine and ultimate sacrifice that would put an end to the infinite chain of animal or even human sacrifices through which mankind considered that they fulfilled their sacred duty to God to the highest degree. Melchizedek expresses the idea of a final, unique, bloodless and profound sacrifice, that mankind would permanently bring to God, as a means of reconnecting with Him. The fact that he is both a priest and a king establishes the two dimensions uniting the vertical with the horizontal, the priesthood being the vertical and the royalty designating the horizontal nature of the relation between God and man and that between men and Creation. A mystery of mankind, Melchizedek symbolizes the enigma of Christ that our mind is not able to unfold, being the Liturgy of life. The King of Salem is the first king in a fortress that would eventually be replaced by David's Tower, where Solomon's Temple was erected.

Today the symbolism of the city of Salem provides the chance of constructing the Third Temple of Jerusalem. In the Jewish tradition, the First Temple of Jerusalem was not built on today's platform of Al-Aqsa Mosque. The Temple of Solomon was erected in the city of David, which was 600 paces further down the corner of the Western Wall or the Wailing Wall. The Gihon spring, the main water source had also been located in Jerusalem since the city of David was in the possession of the Jebusites. With a capacity of 600.000 cubic meters per year, this spring constituted Jerusalem's most ancient water supply. It was said that whoever wanted to capture Jerusalem, first he had to find its source of water. Archaeologits argue about the first 
location of Solomon's Temple ${ }^{5}$. They support the idea that the temple was built 300 paces further down the Western Wall, not on the platform of the Temple (where the Dome of the Rock and the Al-Aqsa Mosque were erected). If this be true, Solomon's Temple ot the Third Temple could be reconstructed without destroying the Al-Aqsa Mosque and causind a Third World War. In the city of David an axis mundi of the Jewish faith must have been present and it led to messianic practice. The connection between heaven and earth was created there and it is also there that the theophanies which formed a Messianic people occurred.

Muslims also claim Abraham is one of their prophets ${ }^{6}$. Although he is spoken of both in the Old Testament and in the Quran, these individual scriptures were written at different times. First of all, it's about the period of time. Moses wrote about Abraham and Moses lived around 1400 BC., while the Quran was written in the year 650. So, there is a difference of about 2000 years. The truth has always been more exact when things happend and not 2000 years later. In other words, the Old Testament is much more convincing when referring to Abraham. But what are the differences between Islam and Judaism when speaking about the great prophet?

First of all, events are different in Islam. Abraham's main wife was not Sarai, but Hagar, the Egyptian, presumably a pharaoh's daughter. The Islam tradition holds that Abraham banished Sarai and Isaac and that he took Agar to Mecca where he found the Zamzam well. There Abraham constructed the

5 About this issue see John M. LundQuist, The Temple of Jerusalem. Past, Present and Future, Praeger Publisher, London, 2008.

6 "In post-Quranic Islamic tradition, Ishmael is exalted as the beloved son whom Abraham almost sacrifices, and Ishmael and Abraham together build the holy shrine of the Kaaba in Mecca" said Ronald HENDEL, in Remembering Abraham. Culture, Memory and History in the Hebrew Bible, Oxford University Press, 2005, p.12. 
Kaaba for the worship of Allah. Over the years, that place of prayer was filled with pagan deities before Muhammad destroyed them all. But there are some contradictions that prove the Old Testament speaks the truth. First of all, the relationship between Abraham and his real wife. If Agar had been his wife and not Sarai's handmaid, why is he not buried with her, but buried with Sarai in the cave of Machpelah in Horeb, where all Jewish patriarchs are inhumated (Isaac and Jacob alongside their wives)? The great patriarch Abraham, who is is seen as the father of the Arab people as well as the Jewish people, was buried alongside Sarah, not Hagar or Agar.

Secondly, suppose Abraham went to Mecca and turned it into a great religious centre. He built a temple there, the Kaaba and placed the Black Stone he had received from Allah in the Eastern corner of the structure. The question is why Abraham did not remain in the great city of Mecca to be buried there. Why did he come back be buried in the tomb of the Patriarchs? Why was he buried at Shechem, Mamre Oak, in the cave of Macpelah, where only the Patriarchs of the Old Testament rested? And when Saladin reclaimed the city of Hebron, the church built over the tombs was transformed into a mosque, which means that the Muslims admit that is Abraham's tomb. Yet, there is another question. Why did Abraham come back to Sarah, the slave (as she is seen by Muslims) and why did he leave Agar? Why was Ishmael not buried near his father and why was Isaac buried there instead?

King Herod the Great (31 BC - 4 AD) built a high, fortified wall around the Tomb of the Patriarchs which still stands today. Later this area was cleared by the Roman troops, and Emperor Hadrian erected a temple on Herod's ruins. Then, after agreement to treat Christians benevolently within the Roman Empire, Empress Helen built a church, and two hundred years later, Emperor Justinian constructed another magnificent church. 
Unfortunately, the rise of Islam meant its conversion into a mosque. The Mosque was rebuilt as a church by the Crusaders who had discovered the entrance to the cave and made it easy to visit and rever the six graves (Abraham and Sarah, Isaac and Rebecca, Jacob and Leah). After the Crusaders had been defeated, Saladin reconverted the church into a mosque.

Between 1266 and the 1800s, the Christians and the Jews were not allowed to enter these places of worship and they had no access to the cenotaphs. In fact, the cenotaphs were taken out of the caves and rebuilt in the mosque as marble domed monuments. Unfortunately, there was an ongoing tension in this place of worship where one was supposed to find peace. In 1922 there was a minority of four hundred Jews, compared to over 16.000 Palestinians. A few years later (in 1929) the Jewish community was massacred by the Palestinians and the survivors were forced to leave Hebron. After the six-day war of 1967, the soldiers took over Hebron and gained access to the sanctuary after 1000 years. Unfortunately, after the 1994 massacre, when 29 Palestinian worshippers were killed, things got worse and the place was not safe at all. It is a shame, because Abraham was the father of both the Jewish people and the Arab people. These two peoples in conflict prove that there cannot be peace between Isaac and Ishmael. And this is one of the many problems that has turned the Holy Land into the most tense area in the world instead of being the place of divine peace.

In conclusion, our study referring to Abraham ends here and we conclude he is the most extraordinary figure of the Old Testament. He is the father of two peoples who could view him as a connection between them instead of being the bone of contention. However, Abraham offers the three faiths the chance to connect with each other since they all share him and believe in his one true God. Abraham is a starting point in the interfaith dialogue among Muslims, Christians, and Jews, ensuring the 
common language in search of a connection that provides the peace so much needed by most of the people in the world.

\section{References}

1. Burell, David B., Carlo Cogliati, Janet M. Soskice, William R. Stoeger, Creation and the God of Abraham, Cambridge University Press, 2010.

2. CATHERwood, Christopher, A brief History of the Middle East. From Abraham to Arafat, Caroll and Graff Publisher, New York, 2006.

3. FEILER, Bruce, Abraham. A Journey to the Heart of Three Faiths, Harper Collins Publisher, 2002.

4. Goodman, Lenn Evan, God of Abraham, Oxford University Press, New York (s.a.), 1996.

5. HENDEL, Ronald, Remembering Abraham. Culture, Memory and History in the Hebrew Bible, Oxford University Press, 2005.

6. Hughes, Aaron, Abrahamic Religions. On the Uses and Abuses of History, Oxford University Press, 2012.

7. LundQuist, John M., The Temple of Jerusalem. Past, Present and Future, Praeger Publisher, London, 2008.

8. Ollenburger, Ben C., Zion, the Cuty of the Great King. A Theological Symbol of the Jerusalem Cult, JSOT Press, Sheffield, 1987.

9. OREN, Michael B., Six Days of War. June 1967 and the Making of the Modern Middle East, Oxford, University Press, 2002. 